\title{
Clinical and Etiological Profile of Ascites in the Departmental University Hospital of Porto-Novo
}

\author{
Jean Sehonou1, Finangnon Armand Wanvoegbe ${ }^{2}$, Aboudou Raïmi Kpossou1, \\ Kouessi Anthelme Agbodande ${ }^{3}$, Josiane Dossou ${ }^{2}$, Angelo Attinsounon ${ }^{2}$, Adebayo Alassani2, \\ Angèle Azon-Kouanou ${ }^{3}$, Albert Dovonou' ${ }^{2}$, Marcel Zannou3 ${ }^{3}$, Fabien Houngbe ${ }^{3}$
}

\author{
${ }^{1}$ Hepato-Gastroenterology Department, HKM University Hospital, Cotonou, Benin \\ ${ }^{2}$ Internal Medicine Department, Departmental University Hospital, Porto-Novo, Benin \\ ${ }^{3}$ Internal Medicine Department, HKM University Hospital, Cotonou, Benin \\ Email: jsehonou@yahoo.fr, ‘wafinarm@yahoo.fr, kpossou.raimi@yahoo.fr, agbotem@yahoo.fr, josie.dossou@yahoo.fr, \\ acosange@yahoo.fr, adebayoalassani@gmail.com,dovcom1@yahoo.fr, angele_kouanou@hotmail.com, \\ djmzannou@yahoo.fr, fab2012jos@yahoo.com
}

How to cite this paper: Sehonou, J., Wanvoegbe, F.A., Kpossou, A.R., Agbodande, K.A., Dossou, J., Attinsounon, A., Alassani, A., Azon-Kouanou, A., Dovonou, A., Zannou, M. and Houngbe, F. (2017) Clinical and Etiological Profile of Ascites in the Departmental University Hospital of Porto-Novo. Open Journal of Gastroenterology, 7, 197205.

https://doi.org/10.4236/ojgas.2017.77021

Received: May 22, 2017

Accepted: July 23, 2017

Published: July 26, 2017

Copyright $\odot 2017$ by authors and Scientific Research Publishing Inc. This work is licensed under the Creative Commons Attribution International License (CC BY 4.0).

http://creativecommons.org/licenses/by/4.0/ cc) (i) Open Access

\begin{abstract}
Aim: To determine the frequency, the clinical and etiological aspects of ascites in the Internal Medicine Division of the University Hospital of Porto-Novo. Methods: It was a cross-sectional study with a descriptive focus covering the period from January 16 to August 31, 2015. It covered patients hospitalized for ascites in Internal Medicine Department at the Departmental University Hospital of Porto-Novo during the study period. Data were collected on a survey sheet and entered by Excel and analyzed with SPSS. The Chi-square test was used for statistical analysis and a significance threshold of 5\% was retained. Results: Of the 511 hospitalized patients during the study period, 61 (11.9\%) had ascites. The mean age was $49.6 \pm 13.6$ years with extremes of 19 years and 80 years. There was a male predominance with a sex ratio of 2.05 . Ascites were often type III (34 patients, 55.7\%), or type II (22 patients, 36.1\%). The frequent signs were hepatomegaly (65.6\%), splenomegaly (45.9\%), pelvic limb edema (44.3\%), and abdominal collateral venous circulation (39.3\%). The macroscopic appearance of the ascites fluid was dominated by citrin yellow $(82 \%)$, followed by hazy $(11.5 \%)$. The hematic appearance was found in $6.5 \%$ of the cases. Hepatic cirrhosis was the most frequent etiology (34.4\%) followed by overall heart failure (21.0\%). Hepatocellular carcinoma was found in $16 \%$ of cases and nephrotic syndrome in $10 \%$ of cases. Conclusion: The etiological diversity of ascites, found in our study, imposes a careful clinical and paraclinical approach.
\end{abstract}




\section{Keywords}

Ascites, Etiology, Porto-Novo, Benin

\section{Introduction}

Ascites is a fluid extravasation in the peritoneal cavity. Its etiological diagnosis requires careful clinical examination and a cautious choice of complementary examinations. Generally, ascites is a very common manifestation of decompensation of hepatic cirrhosis [1] [2]. Ascites decompensates $60 \%$ of cirrhosis in the first 10 years after the onset of the disease [3]; the hepatic origin of ascites ranges from $75 \%-85 \%$ [4]. In France, $80 \%$ of ascites are linked to cirrhotic hepatopathy, mostly alcoholic-related origin [5].

In Sub Saharian Africa, cirrhosis is a less frequent cause of ascites, as shown by a study in Mali in which it counted for $23.3 \%$ of cases of ascites [6]. In Benin in 2006, in a study of liver cirrhosis conducted in the main University Hospital of Cotonou, ascites was found in $61.53 \%$ of patients [7] in Hepato-gastro-Enterology Department. No studies have been carried out on ascites in Porto-Novo. The objective of this study was to determine the frequency, clinical and etiological aspects of ascites in Internal Medicine Department at the Departmental University Hospital of Porto-Novo.

\section{Methods}

The study was transversal with a descriptive purpose and carried out from January 16 to August 31,2015. The study was carried out on all hospitalized patients with ascites admitted in Internal Medicine Department at the Departmental University Hospital of Porto-Novo during the period. Were included, all patients with clinically-proved or discovered abdomino-pelvic ultrasound and confirmed during a puncture. Patients with haemoperitoneum or pyoperitoneum were not included. We conducted a systematic, non-probabilistic recruitment of all hospitalized patients with ascites in the department. Ascites was a dependent variable. Independent variables were: demographics, history, clinical and paraclinic characteristics, and etiologies. All patients included underwent an extensive physical examination and had a paraclinical assessment according to the etiological orientation of each case. No liver biopsy or laparoscopy was performed. The patients were informed about the nature of the study and the impact the results could have on their care. The fact sheets were completed in anonymity by means of an identification number guarantying the confidentiality of the data.

Data were recorded on a survey sheet and entered in Excel and analyzed with SPSS. Data processing was made with Microsoft Word 2010. The chi-square test was used for statistical analysis. The level of statistical significance retained was $5 \%$. 


\section{Results}

A total of 511 patients were hospitalized in Internal Medicine of the Departmental University Hospital of Porto-Novo. Of these patients, 61 had ascites and were booked as a sample of our study, which is a hospital prevalence of $11.9 \%$.

\subsection{Socio-Demographic Characteristics of the Study Population (Table 1)}

The mean age was 49.6 years 13.6 with extremes 19 years and 80 years.

The sex ratio was 2.05 with a male representing $67.2 \%$ of the cases.

Patients mostly lived in urban areas 33 (54.1\%) with 28 (45.9\%) in rural areas. At the professional level, traders $(24.6 \%)$ and craftsmen $(18.0 \%)$ were the most represented.

\subsection{Clinical Characteristics}

\subsubsection{Distribution by Abundance of Ascites}

Most patients in our sample had type III ascites (34 patients, 55.7\%), followed by those with type II ascites $(22,36.1 \%)$. Type I was present in only $8 \%$ of patients.

\subsubsection{Distribution of Patients by Associated Signs}

Forty (40) patients (65.6\%) had hepatomegaly, 28 (45.9\%) had splenomegaly and 27 (44.3\%) had pelvic limb edema. Collateral venous circulation was associated with ascites in $39.3 \%$ (Table 2).

\subsubsection{Distribution According to the Macroscopic Aspect of the Liquid} The macroscopic appearance of the ascites fluid was dominated by citrin yellow $(82 \%)$, followed by hazy $(11.5 \%)$. The hematic appearance was found in $6.5 \%$ of the cases.

\subsection{Distribution by Etiology}

Hepatic cirrhosis was more prevalent in patients $(34.4 \%)$ followed by overall heart failure (21.0\%). Hepatocellular carcinoma was found in $16 \%$ of cases and nephrotic syndrome in $10 \%$ of cases (Figure 1 and Table 3 ).

Table 1. Characteristics of study population.

\begin{tabular}{cc}
\hline Variables & Population $\boldsymbol{n}=\mathbf{6 1}$ \\
\hline Median age & $49.6(19-80)$ \\
Sex (M/F)\% & $67.2 / 32.8$ \\
Geographical zone (\%) & \\
Urban & $33(54.1)$ \\
Rural & $28(45.9)$ \\
Alcoholism (\%) & $25(41.0)$ \\
Hypertension (\%) & $18(29.5)$ \\
Smoking (\%) & $18(29.5)$ \\
Diabetes (\%) & $4(6.6)$ \\
History of jaundice (\%) & $3(4.9)$ \\
\hline
\end{tabular}




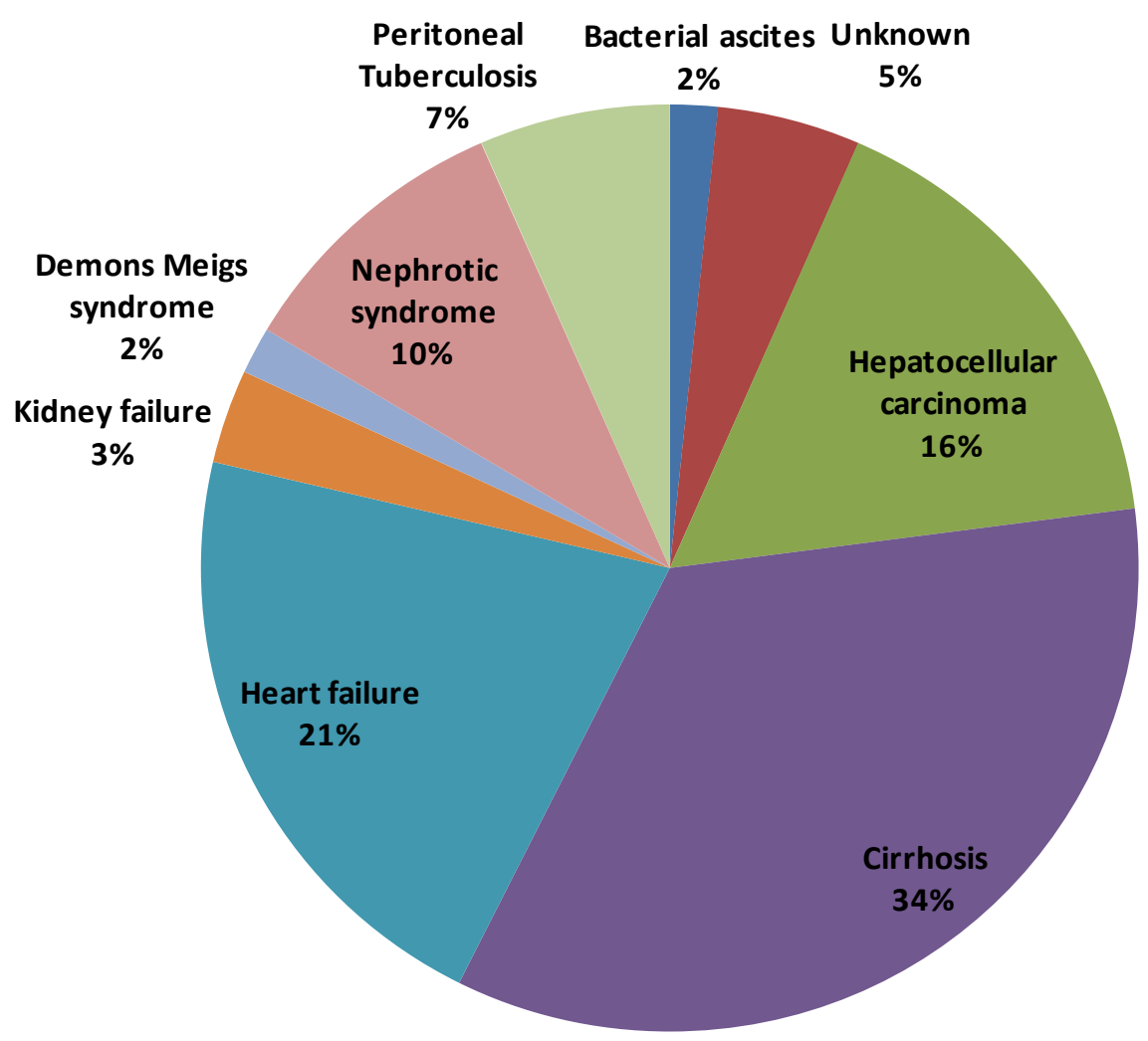

Figure 1. Distribution of ascites according to etiology.

Table 2. Distribution of patients according to ascites-associated signs.

\begin{tabular}{ccc}
\hline Signs & Number & Frequency \\
\hline Hepatomegaly & 40 & 65.6 \\
Splenomegaly & 28 & 45.9 \\
FE & 27 & 44.3 \\
C.V.C & 24 & 39.3 \\
Jaundice & 17 & 27.9 \\
HT & 16 & 26.2 \\
Tachycardia & 12 & 19.7 \\
Turgescence of the jugular & 10 & 16.4 \\
Hyperthermia & 8 & 13.1 \\
Facial puffiness & 4 & 6.6 \\
Abdominal mass & 1 & 1.6 \\
Digestive haemorrhages & 1 & 1.6 \\
\hline
\end{tabular}

FE: Feet Edema; CVC: Collateral Venous Circulation; HT: Hypertension.

The substantial preponderance of our cirrhotic patients were male (85.7\%). This male majority was also found in hepatocellular carcinoma and heart failure. But the sex ratio was equal to 1 in other etiologies. The hematic appearance of the ascites fluid was found only in peritoneal tuberculosis and cancers (Table 4). 
Table 3. Distribution of aetiology according to macroscopic ascites fluid.

\begin{tabular}{cccc}
\hline \multirow{2}{*}{ Diagnostic } & \multicolumn{2}{c}{ Macroscopic aspect of ascites fluid } \\
\cline { 2 - 4 } & Citrin yellow & Hazy & Hematic \\
\hline Bacterial ascites & 0 & 1 & 0 \\
Peritoneal tuberculosis & 0 & 2 & 2 \\
Hepatocellular carcinoma & 8 & 1 & 1 \\
Cirrhosis & 21 & 0 & 0 \\
Heart failure & 12 & 1 & 0 \\
Kidney failure & 2 & 0 & 0 \\
Syndrome of demons meig & 0 & 1 & 0 \\
Nephrotic syndrome & 6 & 0 & 0 \\
Unknown & 1 & 1 & 1 \\
Total & 50 & 2 & 4 \\
\hline
\end{tabular}

Table 4. Distribution of patients according to the etiological profile, and clinical and biological characteristics.

\begin{tabular}{|c|c|c|c|c|c|}
\hline Cirrhosis & $\mathrm{HCC}$ & $\mathrm{HF}$ & TB & Nephropathies & Unknown \\
\hline Mean age 40 & 60 & 40 & 50 & 40 & 50 \\
\hline \multicolumn{6}{|c|}{ Sex } \\
\hline Male $85.7 \%$ & $60 \%$ & $69.2 \%$ & $50 \%$ & $50 \%$ & $50 \%$ \\
\hline Female $14.3 \%$ & $40 \%$ & $30.8 \%$ & $50 \%$ & $50 \%$ & $50 \%$ \\
\hline \multicolumn{6}{|c|}{ Motive for consultation } \\
\hline abdominal mass+ & + & & + & & + \\
\hline Abdominal mass-OMI & & & & + & \\
\hline Dyspnoea & & + & & & \\
\hline \multicolumn{6}{|c|}{ Abundance of ascites } \\
\hline Type I & & + & & + & \\
\hline Type II+ & + & + & + & ++ & + \\
\hline Type III++ & + & & & & \\
\hline \multicolumn{6}{|c|}{ Ascites fluid aspect } \\
\hline Citrin yellow 100\% & $80 \%$ & $92.3 \%$ & & $100 \%$ & $25 \%$ \\
\hline Unclear & $10 \%$ & $7.7 \%$ & $50 \%$ & & $50 \%$ \\
\hline Hematic & $10 \%$ & & $50 \%$ & & $25 \%$ \\
\hline \multicolumn{6}{|c|}{ Proteins rate } \\
\hline Higher to $30 \mathrm{~g}$ & & + & + & & + \\
\hline Lower to $30 \mathrm{~g}+$ & + & & & + & + \\
\hline
\end{tabular}

HCC: Hepatocellular Carcinoma; HF: Heart Failure; TB: Tuberculosis; FE: Feet Edema. 


\section{Discussion}

This transversal and descriptive study made it possible to note a hospital prevalence of $11.94 \%$ for ascites. Our incidence is superimposable to that of Bambara [8] which was 11.4\% in Burkina Faso in 2013, but higher than those found by Sidibé [6] 3.68\% in Mali in 2009 and Ouattara et al. [9] 3.6\% in Côte d'Ivoire in 2014. It is less than $75 \%$ described in 2010 by Sehonou et al. at the University Hospital of Cotonou. This high frequency in Cotonou is explained by the fact that it was a study carried out in a cirrhotic patient population.

In the present study, a male predominance was noted with a sex ratio of 2.05. This male predominance could be explained by the overexposure of men to etiological factors of cirrhosis (alcoholism, hepatitis B) which is the main cause of ascites in our series. To this could be added the relative protection of women during periods of genital activity against hepatic fibrosis: hormones play a preponderant role here. This male predominance is found in the majority of studies but in variable proportions: Drabo et al. [10] at Ouagadougou University Hospital in 1996, Dembélé et al. [11] in Mali in 2009, Ouattara et al. [9] in Côte d'Ivoire and Doumbia et al. [12] in Mali in 2012.

On the other hand, the study by Sidibé [6] reports a sex ratio of 1.2 in favor to women.

The trend in the sex ratio of liver diseases is expected to reverse: Hepatitis B will tend to decline due to a widespread vaccination; those associated with metabolic syndrome (steatohepatitis) will tend to increase. The most affected age group in our study population is adults aged from 30 to 60 years. This age group, which represents the productive force, particularly in the developing countries, counts for $68.3 \%$ of the patients in the sample.

The most affected age groups according to Sidibé [6] and Dembélé [11] are respectively 20 - 40 years, $21-60$ years. The median age of our population is 49.56 years 13.56 with 19 and 80 years as extremes, these results almost similar to those of Ouattara et al. [9], and Bambara et al. [8]. The latter had found a mean age of 44.6 years with extremes: 19 and 80 years and $46.9 \pm 16.6$ years with extremes: 16 and 90 years.

The relatively young age of our patients could be explained by the etiology of ascites: in our context, the etiology of ascites is dominated by hepatopathies among which viral hepatitis (HBV) is a risk factor. Nevertheless, its transmission is mother to child related, especially horizontal during early childhood and remains long in the subclinical stage [13]. The most common reason for consultation was the increase in the volume of the abdomen (75.4\%). In this case, our result is close to that of Ouattara et al. (74.7\%) [9].

The other patterns were dyspnea (13.11\%), edema (8.2\%) and abdominal mass (3.3\%).

34 patients (55.7\%) had type III ascites followed by type II ascites (22 patients, 36.1\%). These results are consistent with the data of African series in relation with the delay of patients' consultation. Dembélé et al. [11] found $53.6 \%$ and $31 \%$ respectively for type II and type III ascites. As for Ouattara et al. [9], they 
found $48.8 \%$ for type II ascites and $44.4 \%$ for type III ascites.

In fact, abdominal distension is considered in our communities as a waterfilled earthenware jar mystically introduced into the abdomen [9]. Patients only go to hospital in extreme recourse, after having consulted several traditional healers unfruitfully. Hepatomegaly was the most common clinical sign, found in $65.6 \%$ of cases. Other common signs were lower extremity edema (44.3\%), splenomegaly (45.9\%), collateral venous circulation (39.3\%), and jaundice (27.9\%). Hepatomegaly was also the main morphological change reported by other authors [7] [14]. Splenomegaly and collateral venous circulations were noted in $13 \%$ and $5.5 \%$ by Bouglouga in Togo, in $28 \%$ and $30.77 \%$ by Sehonou et al. in Cotonou [7].

Cirrhosis was the most frequent etiology in our study with a rate of $34.4 \%$ or one case in three, associated with a male predominance. This frequency was similar to that found by Dembélé [11] in his series with 37.3\%. Compared to our study, these series pose a problem of recruitment bias. They recruited only patients recorded in Hepato-Gastroenterology Department; on the other hand our study took place in inpatient department.

Although higher, our results were lower than those of Ouattara et al. [9] 61.9\% and Kombila et al. [14] 44.4\%. These are retrospective studies carried out over 5 years and 10 years respectively.

In France, the presence of ascites is linked to a hepatopathy, mainly cirrhotic, in $80 \%$ of cases, mainly of alcoholic origin [5]. This may be related to the low prevalence of viral hepatitis in France than in African countries. Heart failure was found in $21.3 \%$ of our patients. This result is higher than that of Kombila et al. [14], Sidibe [6] who reported $9 \%$ and $7.5 \%$, respectively. The male sex was affected as well as the female. This could be explained by the prevalence of hypertension (the main cardiovascular risk factor) in both sexes in Benin: $27.2 \%$ in men; 26.3 in women [15] and the recrutment of patients with cardiovascular disease in the internal Medicine department.

It is rather close to that reported by Ouattara et al. [9] 19\%, women were more represented (83.4\%). In a study by Traoré in Mali [16], on the digestive manifestations of heart failure, ascites cause was found in 11 of 35 patients with a female predominance.

In our study, a malignant transformation of cirrhosis was noted in several patients. Alpha Foeto Protein levels were elevated in $16.4 \%$ of patients. In these cases, an ultrasound has individualized hepatic nodules greater than $2 \mathrm{~cm}$. Men over 60 were frequently affected. This result is consistent with the literature's finding that $\mathrm{CHC}$ occurs frequently in humans and grows linearly with age. This may be related to prolonged human exposure to the viral hepatitis [17]. The hospital frequency of ascites due to hepatocarcinoma in Lomé, according to Bouglouga et al. [18] was 5.1\% with a male predominance (sex ratio 2.9). It was 2.54\% in Abidjan for Mahassadi KA et al. [19].

Nephropathies were found in $13.1 \%$ of our patients. Ouattara et al. [9] report in Côte d'Ivoire a higher frequency than ours (17.2\%). As for Kombila et al. [14] nephropathies counted for $7.9 \%$ of their series. 
Peritoneal tuberculosis counted for $6.7 \%$ of the causes of ascites in our study. This prevalence is likely to be underestimated. Indeed, PCR (GenXpert) was performed in patients according to the diagnostic orientation. Bambara [8], Kombila et al. reported a peritoneal tuberculosis incidence in $11.3 \%$ of abdominal conditions and $22.7 \%$ of laparoscopic cases respectively. In the study of Mallé [20], abdominal tuberculosis was found in $15.07 \%$ of ascites. On the other hand, Dembélé [21] found a lower rate of $4.13 \%$. In Mali, a female predo-minance was found in the study by Traoré et al. [22], peritoneal involvement can be achieved from a genital focus by contiguity.

We noted $5 \%$ of indeterminate cases. No laparoscopy had been performed due to the unfavorable technical background and the limited financial resources of the patients. This exam could show granulomatosis diseases of peritoneum.

\section{Conclusion}

Our study allowed us to have an overview of the clinical and etiological aspects of ascites in the Departmental University Hospital of Porto-Novo. This etiological diversity must therefore impose a rigorous diagnostic approach. Careful inquisition should seek the patient's antecedents and related ascites symptoms, which have an etiological orientation value. Physical examination should not be restricted to the digestive tract as the cause may be extra digestive. These two steps will allow a difficult selection of the paraclinical examinations according to the orientation of the diagnosis.

\section{References}

[1] Soren, M., Jens, H. and Flemming, B. (2009) Ascites: Pathogenesis and Therapeutic Principles. Scandinavian Journal of Gastroenterology, 44, 902-911. https://doi.org/10.1080/00365520902912555

[2] Moore, C.M. and Van Thiel, D.H. (2013) Cirrhotic Ascites Review: Pathophysiology, Diagnosis and Management. World Journal of Hepatology, 5, 251-263. https://doi.org/10.4254/wjh.v5.i5.251

[3] European Association for the Study of the Liver (2010) Clinical Practice Guidelines on the Management of Ascites, Spontaneous Bacterial Peritonitis, and Hepatorenal Syndrome in Cirrhosis. Journal of Hepatology, 53, 397-417. https://doi.org/10.1016/j.jhep.2010.05.004

[4] Pexa-Tittia, E., Raisinb, J. and Frenzera, A. (2012) Ascites: Etiologies, Investigations and Treatment. Forum Médical Suisse, 12, 951-954.

[5] Bresson-Hadni, S. (2000) Diagnostic Guidance and Management in the Presence of Ascites. Lettre de l'Hépato-Gastroentérologue, 3, 189-92.

[6] Sidibe, A. (2009) Ascites: Clinical Presentation and Aetiological Profile of Ascites in the Department of Hepato-Gastroenterology of CHU Gabriel TOURE. Ph.D. Dissertation, University of Bamako, Bamako.

[7] Sehonou, J., Kodjoh, N., Sake, K. and Mouala, C. (2010) Hepatic Cirrhosis in Cotonou: Factors Related to Death. Médecine tropicale, 70, 375-78.

[8] Bambara, M.L. (2013) Epidemiological, Diagnostic, Therapeutic and Evolutionary Aspects of Ascites in the Department of Medicine of the Bobo-Dioulasso University Hospital Center. Ph.D. Dissertation, Higher Institute of Health Sciences, Bobo- 
Dioulasso.

[9] Ouattara, B., Kra, O., Kouassi, L., Kone, S., Biekre, R., Toure, K.H., et al. (2014) Aetiologies of Ascites in a Department of Internal Medicine in Côte d'Ivoire. African Journal of Internal Medicine, 3, 56-59.

[10] Drabo, Y.I., Some, M.L., Kabore, J., Sawadogo, S., Lengani, A., Traore, R. et al. (1996) Morbidity and Mortality in the Internal Medicine Department of the Ouagadougou National Hospital Center over 4 Years. Médecine d'Afrique Noire, 43, 655-659.

[11] Dembele, Y. (2006) The Etiology of Ascites in the Department of Internal Medicine in the C.H.U of Point G, about 67 Cases. Ph.D. Dissertation, University of Bamako, Bamako.

[12] Doumbia, K., Diarra, M., Konate, A., Sow, H., Soukho, A., Kalle, A. et al. (2012) Ascites, a Pejorative Complication in Cirrhotic in Tropical Environments. Médecine d'Afrique Noire, 59, 274-278.

[13] Hountondji, J.A. (1983) Morbidity and Mortality in the Department of Internal Medicine, CNHU, Cotonou. Ph.D. Dissertation, University of Abomey Calavi, Abomey Calavi.

[14] Kombila, U.D., Iba Ba, J., Obamegwa, C., Mounguengui, D.D., Itoudi Bignoumba, E.P., Ondo Mba, L.B. et al. (2012) Etiological Profile of Hospital-Based Ascites in Libreville. Médecine d'Afrique Noire, 59, 491-495.

[15] Houinato, D., Segnon Agueh, J.A., Djrolo, F. and Djigbennoude, O. (2008) Final Report of the STEPS Survey in Benin. National Directorate of Health Projection, National Program for the Control of Non-Communicable Diseases, Cotonou.

[16] Traore, F.D. (2009) Digestive Manifestations during Heart Failure in the Medical Department of the CHU Gabriel Touré. Ph.D. Dissertation, University of Bamako, Bamako.

[17] Diarra, M., Konate, A., Dembele, M., Kone, B., Wandji, M.J., Maiga et al. (2006) Hepatocellular Carcinoma: Clinical and Evolutionary Epidemiological Aspects. Médecine d'Afrique Noire, 53, 23-28.

[18] Bouglouga, O., Bagny, A., Lawson-Ananissoh, L.M., Djibril, M.A., Redah, D. and Agbetra, A. (2012) Does the Management of Hepatocellular Carcinoma Progress in Black Africa. Revue Médicale de Madagascar, 2, 176-179.

[19] Mahassadi, K.A., Attiaka, K.A., Bathaix, Y.F., Kissi, Y.H., Assohoun, K.T. and Ndri-Yoman, T.H. (2005) Clinical Manifestations and Predictive Factors of Hepatocellular Carcinoma in Abidjan (Côte d'Ivoire). Médecine d'Afrique Noire, 52, 602-608.

[20] Malle, O. (2008) Abdominal Tuberculosis in the Medical Services of the CHU of Gabriel Toure and Point "G”. Ph.D. Dissertation, University of Bamako, Bamako.

[21] Dembele, M, Maiga, M.Y., Minta, D.K., Traore, S.A., Sacko, M., Traore, A.K., et al. (2003) Peritoneal Tuberculosis in a Department of Internal Medicine in Tropical Environment: Clinical, Biological and Laparoscopic Aspects. Acta Endoscopica, 33, 561-567. https://doi.org/10.1007/BF03002421

[22] Traore, A.H., Maiga, M.Y., Dembele, M., Diallo, A., Traore, A.K., Sidibe, A., et al. (1998) Current Etiologies of Abdominal Granulomatosis in Mali. Place of Laparoscopy. Médecine et Chirurgie Digestives, 27, 283-285. 
Submit or recommend next manuscript to SCIRP and we will provide best service for you:

Accepting pre-submission inquiries through Email, Facebook, LinkedIn, Twitter, etc. A wide selection of journals (inclusive of 9 subjects, more than 200 journals)

Providing 24-hour high-quality service

User-friendly online submission system

Fair and swift peer-review system

Efficient typesetting and proofreading procedure

Display of the result of downloads and visits, as well as the number of cited articles Maximum dissemination of your research work

Submit your manuscript at: http://papersubmission.scirp.org/

Or contact ojgas@scirp.org 